\title{
Cytological Diversity and Seed Storage Protein Profiling of most potent Bauhinia species
}

\author{
Kumari Nutan Sinha ${ }^{1}$ and Tanuja Singh ${ }^{2}$ \\ Department of Botany, B.M.D College, Dayalpur, Vaishali, B.R.A.Bihar University, Bihar
}

\begin{abstract}
To trace the interrelationships and for identification and characterisation of diversity among four species of medicinally important plant Bauhinia viz. B. acuminata, B. purpurea, B. racemosa, and B. variegata belonging to sub-family Caesalpiniaceae, cytological study with respect to chromosome number, somatic chromosome length of component arms of chromosome, T. F\% and chromosome type and seed protein variation were investigated. Results showed that the three species have chromosome number $2 n=28$, the value of the total chromatin lengths was lowest $(53.48 \mu)$ in B. racemosa and highest $(57.32 \mu)$ in B. purpurea while in $B$. acuminata this value was $56.78 \mu$ suggesting a close relationship between B.purpurea and B. acuminata. The $T . F \%$ values of B. acuminata and B. purpurea stand close to each other. Beside the common bands among the studied taxa, $7.37 \mathrm{kDa}, 31.85 \mathrm{kDa}, 41.56 \mathrm{kDa}, 54.854 \mathrm{kDa}$ and $261.143 \mathrm{kDa}$ proteins were found to be common in B. acuminata and B. purpurea and $261.143 \mathrm{kDa}$ protein was found common in all the four species. Maximum genetic affinities were observed between B. acuminata $\times$ B. purpurea (45.45\%), while minimum between and $B$. racemosa and B. variegata (20\%). On the molecular level, the present study gave the results with wide variations in their band numbers. Maximum number of protein bands (11 bands) was observed in $B$. racemosa, while minimum (7 bands) in B. purpurea and B. variegata.
\end{abstract}

Key words: Bauhinia, Karyotypes, Electrophoresis, Storage -protein

\section{Introduction :}

Genus Bauhinia is the largest genera of the family Caesalpiniaceae which represents more than 300 species. It is the largest genus in the legume tribe Cercideae, sub tribe Bauhiniiae [1,2,3,]. Bauhinia genus consisting of trees, climbers and shrubs and is distributed in India [4]. It has great medicinal value.

The genus was originally named by Charles Plumier (1703), because the emarginated apical cone of leaves symbolized to him two Swiss botanist the (Bauhin brother, John, 1541-1613 and Caspar, 1560 -1624). Casper and Bauhin born in France but who lived and worked in Switzerland during the latter half of the $16^{\text {th }}$ and the first part of the $17^{\text {th }}$ Century. The name was accepted by Linneaus in 1753. In India, 15 species of the genus Bauhinia L. is reported [5] but the commonest are B. variegata, B. purpurea, B. acuminata and B. tomentosa. From Bihar and Orissa, 9 species have been reported in the 'Flora of Bihar and Orissa' $[6]$.

Due to variation in their morphological structure, cytogenetic and the study of seed storage protein can be of great help in tracing interrelationships among the species. The basic chromosome number is one of the most widely used characters in Biosystematics. However, chromosome numbers are only of limited utility for tracing evolutionary relationship. Cytologically, the genus Bauhinia is characterized by a uniform chromosome number of $2 \mathrm{n}=28$, except Bauhinia monandra which has 42 chromosomes[7,8].

The seed storage protein analysis helps in identification and characterisation of diversity in crop varieties and also provides information on phylogenetic relationship of the accession [9,10,11]. Electrophoresis of protein is a powerful tool for identification of genetic diversity and the SDS-PAGE is particularly considered as a reliable technology because seed storage proteins are highly independent of environmental fluctuations[12, 13]. Seed protein patterns can also be used as a promising tool for distinguishing cultivars of particular crop species $[14,15]$. The SDS-PAGE is considered to be a practical and reliable method for species identification [16].

Since in mature seeds, type and amount of proteins are more constant than other plant tissues [17] therefore, the SDS-PAGE pattern of seed storage proteins of selected species showed polymorphism on the basis of difference in protein intensity among genotypes.

To trace the interrelationships and for identification and characterisation of diversity among four species of medicinally important plant Bauhinia viz. B. acuminata, B. purpurea, B. racemosa Lam. and $B$. variegata, cytological study with respect to chromosome number, somatic chromosome length of component arms of chromosome, T.F\% and chromosome type and seed protein variation were investigated by light microscopic study and SDS-PAGE technique respectively. 


\section{Materials and methods:}

1.1 Cytological Studies: For studying the somatic chromosomes, seeds of selected species of Bauhinia were collected from various localities, were germinated on a moist filter paper in petridish and kept in an incubator at $27^{0}-29^{0} \mathrm{C}$. One to two $\mathrm{cm}$ long root tips of the germinating seeds were cut. They were thoroughly washed with a Camel-hair brush to remove the root cap. The root tips were given a pretreatment in saturated aqueous solution of para di-chlorobenzene for $2 \mathrm{hrs}$ at $15^{\circ} \mathrm{C}$. After pretreatment, the roots were washed and fixed in aceticalcohol mixture (1:3) and kept in refrigerator. In hot weather fixed materials were kept in refrigerator. After removing from fixative, the roots were thoroughly washed in water. Then they were gently warmed in $2 \%$ aceto-carmine repeatedly for 20-25 minutes. The materials were finally transferred to fresh aceto-carmine. The apical part of fresh root tips were cut off and squashed in $2 \%$ acetocarmine. The chromosomes were separated by gentle tapping and squashing of the materials under the cover slip. Then the slide was sealed with paraffin wax for further studies.

2.1 Electrophoretic Study of Seed Storage Protein: 'Fresh mature seeds of selected species of Bauhinia were collected from different localities of Patna.

2.2 Protein Extraction: Protein was extraceted by method given by Jensen and Lixue [18]. Protein was extracted from overnight presoaked seeds in protein solubilization solution $(62 \mathrm{~m} \mathrm{M}$ Tris $-\mathrm{HCl}, \mathrm{pH} 6.8$, $10 \%$ glycerol, $2 \%$ SDS, p- mercaptoethanol and traces of bromophenol blue) then transferred to Eppendorf tube and centrifuged at $14000 \mathrm{rpm}$ for 30 seconds. The supernatent was transferred to a fresh tube and placed into a boiling water bath for 4 minutes.

2.3 SDS-PAGE: SDS-PAGE was done by method suggested by Lamelli [19]. It was performed on a vertical slab gel. Bromophenol blue was added to the supernatant as tracking dye to watch the movement of protein in the gel. Seed protein was analysed through slab type SDS-PAGE using 10\% Separating gel and 4\% Stacking gel.

Molecular weight of different bands were calibrated with a mixture of standard protein markers include Myosin (261.143 kDa), Phosphorylase B (137.190kDa), BSA (102.564 kDa), Ovalbumin (54.854 kDa), Carbonic Anhydrase (37.670 kDa), Lysozyme (orange) (31.854 kDa), Lysozyme (21.769 kDa) and Aprotinin $(7.337 \mathrm{kDa})$.

Protein Electrode buffer solution was poured into the bottom pool of the apparatus. Gel plates were placed in the apparatus carefully so as to prevent bubbles formation at the bottom of gel plated. Equal quantity of extracted protein from each sample along with Protein molecular weight marker (PAGE mark) was loaded with the micropipette into each wells of the gel. The apparatus was connected with constant electric supply. Electrophoresis was carried out at $20 \mathrm{~mA}$ current for 3-4 hours till the tracking dye reaches the bottom of the gel. After electrophoresis, the protein bands were visualized by staining with coomassie brilliant blue G-250 and destained with methanol, acetic acid and water (4:1:5).

2.3.1 Gel Documentation and Analysis: Finally gel was photographed. Molecular weight of protein bands were estimated by their relative mobility.

Pairing affinity or Similarity index was calculated by the method described by the formula.

Bands common to species I and species II $\mathrm{PA}=$

Total bands of the species I and Species II

\section{Results and Discussion:}

The taxa under present investigation have been cytologically examined in details with respect to somatic chromosome length of component arms of chromosome, T.F\% and chromosome type (Table 1). So far chromosome number is concerned, three species viz. B. acuminata, B. purpurea, B. racemosa and B. variegata have chromosome number $2 \mathrm{n}=28$ (Plates 5-8, Fig. 1-4) which was a multiple of seven.

The studied Bauhinia species in general show a gross resemblance in the nature of the karyotype in rather short chromosomes with gradation in size but with no abrupt size difference in complements $[9,20]$. The close scruitiny of the chromosome types worked out while preparing the karyotype and the karyotypic formulae of the species under reference: [B. acuminata $-1 \mathrm{M}(\mathrm{B})+2 \mathrm{Sm}(\mathrm{B})+2 \mathrm{M}(\mathrm{C})+9 \mathrm{Sm}(\mathrm{C})],[$ B. purpurea -3 $\mathrm{Sm}(\mathrm{B})+3 \mathrm{M}(\mathrm{C})+8 \mathrm{Sm}(\mathrm{C})],[$ B. racemosa $-1 \mathrm{M}(\mathrm{B})+2 \mathrm{Sm}(\mathrm{B})+7 \mathrm{M}(\mathrm{C})+4 \mathrm{Sm}(\mathrm{C})]$, and $[$ B. variegata $1 \mathrm{Sm}(\mathrm{A})+3 \mathrm{Sm}(\mathrm{B})+3 \mathrm{M}(\mathrm{C})+7 \mathrm{Sm}(\mathrm{C})]$ amply reveals that $\mathrm{B}$ and $\mathrm{C}$ types of chromosomes are common to 
all while A type of chromosomes are common to B. tomentosa and B. variegata. This is an indications of the fact that these five species represent quite a homogeneous and natural assemblage.

The studied Bauhinia species had small chromosomes and showed a length from $1.41 \mu$ to $3.01 \mu$, which was almost in agreement with other explored species of the genus [9, 20]. Stebbins [21] regarded Caesalpinoideae as primitive within the family, because its species tend to have small chromosomes with relatively symmetrical karyotypes, a trend also found by Kumari and Bir [22] and our data.

Huziwara [23] has suggested that the lower T.F\% value are indicative of highly asymmetrical and advanced karyotypes, while the higher T.F\% value of the species indicative of symmetry of the karyotype as well as relatively primitive in nature. The present karyological studies coupled with minute karyotypic analysis bring to light that the highest T.F\% value recorded in B. racemosa (49.92) indicated its highly asymmetrical karyotypes and relatively primitive nature while lowest T.F\% value in B. purpurea (46.68) indicated its asymmetrical karyotypes and relatively advanced nature. However a near similarity in T.F\% value of rest other species under reference Table-1 indicated their development from common ancestor as a result of minor alteration in the representatives of the types were met with in different species which may considered as criteria for identification of these species.

The karyotype differences in the species of the genera included in the present investigation might have been brought about by the loss or gain in chromatin matter or by translocation and inversion resulting in the shift of position of the centromere or by altering the size of the chromosome. In the opinion of Singh and Roy [24] also, the translocation and inversion homozygotes are expected to be established easily and earlier in naturally self pollinated genera than in cross pollinated plants.

The range of total chromatin length in them varied and it has been observed to be $56.76 \mu$ in $B$. acuminata, $57.66 \mu$ in B. purpurea, $53.48 \mu$ in B. racemosa and $56.98 \mu$ in B. variegata. The total chromatin length in $B$. purpurea was minimum $(53.32 \mu \mathrm{m})$ while total chromatin length in $B$. racemosa was maximum $(57.66 \mu)$, gives an indication that $B$. purpurea is advanced in nature and $B$. racemosa is primitive nature while remaining two species are intermediate between the two.

The difference in the total chromosome length in different species may be due to deletion or retention of the long heterochromatin segment. Darlington [25] recognized diminution in chromosome size as an established mechanism of evolution in plants. Therefore, it is quite possible that some of the species might have evolved either by diminution of chromosome size due to deletions or by increase in chromosome size to duplication. This amply suggest that translocations with duplication of segments in the chromosome arms have played definite roles at the diploid levels in the ancestral form followed by further chromosome doubling leading to the establishment of present divergent $(2 n=28)$. Karyotype studies provide valuable informations about the evolutionary trends and phylogenetic relationships of the species. The external morphology of the chromosomes is, of course well understood with the help of karyotype study. The chromatin length, value of T.F\% and Total chromatin length (TCL) of three species under consideration are summarized in Table $\mathbf{- 1}$.

Seed storage protein was analyzed through SDS-PAGE using 10\% Polyacrylamide gel. The pattern of the total protein content in four species of Bauhinia showed some variation among them( Plate 9, Fig.5). The Rf value between different species ranged from 0.08 to 0.91 (Table-2). The value depect the mobility of the protein on gel surface. Polymorphism was observed in three variable regions i.e. high, medium and low molecular weight. Molecular weight of proteins ranged from $7.37 \mathrm{kDa}$ to $261.143 \mathrm{kDa}$ ). Band 1 ( $\mathrm{Rf}=0.08$, mol. wt. $261.143 \mathrm{kDa}$ ) and band $22(\mathrm{Rf}=0.90$, mol.wt. $7.37 \mathrm{kDa})$ was exactly alike in all the species.

The SDS banding pattern of protein produced 22 bands distributed in all the species including marker with mol. wt. $7.337 \mathrm{kDa}$ to $261.143 \mathrm{kDa}$ (Plate 9, Fig.5). Maximum number of protein bands (11 bands) was observed in B. racemosa, while minimum (7 bands) in B. purpurea and B. variegata. Beside the common bands among the studied taxa, $7.37 \mathrm{kDa}, 31.85 \mathrm{kDa}$ and $261.143 \mathrm{kDa}$ protein were found common in all the four species. $7.337 \mathrm{kDa}, 31.85 \mathrm{kDa}, 49.95 \mathrm{kDa}, 89.74 \mathrm{kDa} 148.622 \mathrm{kDa}, 254.77 \mathrm{kDa}$ and $261.143 \mathrm{kDa}$, proteins were found in $B$. racemosa while $7.337 \mathrm{kDa}, 31.85 \mathrm{kDa}, 41.56 \mathrm{kDa}, 54.854 \mathrm{kDa}$ and $261.143 \mathrm{kDa}$ proteins were found to be common in B. acuminata and B. purpurea. The pairing affinity index calculated on the basis of electrophoric patterns of seed protein. The percentage similarities for five species belonging to genus Bauhinia ranged from $20 \%$ to $45.45 \%$ (Table-3). Maximum amount of pairing affinity was observed between the two species viz. B. acuminata and B. purpurea (45.45\%) while minimum affinity was observed between $B$. racemosa and $B$. variegata $(20 \%)$.

According to the result of SDS-PAGE, the overall pattern of seed - storage protein showed the diversity of Bauhinia species. The diversity in seed storage protein has also been reported by Khan et al.,[26] for wheat varieties.

Collectively, Karyotype and seed storage protein profiling using SDS-PAGE have the potential to make a distribution between species. These parameters provide information about the phylogenetic relationship. 


\section{Conclusion}

Four Bauhinia species were used in order to elucidate their genetic diversity by using karyotypes and SDS-proteins. It could be concluded that the present results, species can differentiate among the studied Bauhinia species with their karyotypes, the value of total chromatin length (TCL) and T.F \%. All of which have shown varying degree of overlapping closest relationship on all the earlier parameter employed in the present investigation. Bauhinia purpurea, Bauhinia acuminata and $B$. variegata showed close while Bauhinia racemosa stand far from these three.

\section{References}

[1] Wunderlin, R.P. Revision of the arborescent Bauhinia (Fabaceae: Caesalpinioideae: Cercideae) native to Middle American. Ann. Mo. Bot. Gard. 70, 1983. 95- 127.

[2] Bruneau A., Forest F., Herendeen P.S., Kligaard B.B. and Lewis G.P. Phylogenetics relationship in the Caesalpinioideae (Leguminosae) as inferred from Chloroplast trnL. Intron Sequences. Systematic Botany, 26. (3), 2001. 487-514.

[3] Kajita, T., H. Ohashi, Y. Tateishi, C.D.Baily and J.J.Doyle. RbcL. and Legume phylogeny, with particular reference to Phaseoleae, Millettieae and allies. Systematics Botany 26, 2001. 515-536.

[4] Valdir C. Chemical Composition and Biological potential of plants from the genus Bauhinia. Phytother Res 23, 2009.

[5] K.R.Kirtikar, B.D Basu, Indian Medical Plants, (International Book Distributor Dehradun). 1999. pp. 892-901.

[6] Haines, H.H.(1921-1925). The Botany of Bihar and Orissa. Adland and son and Newman.Ltd., London.

[7] Pantulu, J.V. Chromosome numbers of some Caesalpiniaceae. Curr. Sci. 11, 1942. 152-193.

[8] Sharma, A. K and D.T.Raju. Structure and behaviour of chromosomes in Bauhinia and allied genera. Cytologia 33, 1968. 411426.

[9] Nisar, M. A Ghafoor, M.R. Khan, H. Ahmad, A.S. Qureshi \& H. Ali. Genetic diversity and geographic relationship among local \& exotic chickpea germplasm. Park. J. Bot. 39, 2007, 1575-1581.

[10] Tanksley. S.D and Jones R.A. Application of alcohol dehydrogenase allozymes in testing the genetic purity of $F_{1}$ hybrid of tomato. Hort. Sci., 16, 1981. 179-1871.

[11] Thanh V.O.C and Hirata Y. Seed storage protein diversity of three rice species in the Mekong Datta. Biosphere conservation4, 2002. 59-67.

[12] Javid, A., A. Ghafoor and R. Anwar. Seed Storage Protein electrophoresis in ground nut for evaluating genetic diversity. Pak. J. Bot., 36, 2004, 87-96.

[13] Iqbal, S.H., Ghafoor A. and Ayub, N. Relationship between SDS-PAGE markers and Ascochyta blight in chickpea, Pakistan Journal of Botany, 37 (1), 2005. 87-96.

[14] Jha, S.S. and Ohri, D. Phylogenetic relationships of Cajanus cajan (L.) Millsp. (pigeonpea) and its wild relatives based on seedprotein profiles. Genetic Resources and Crop Evolution, 43(3), 1996. 275-281.

[15] Seferoglua, S., Seferoglua, H. G., Tekintasa, F.E and Baltab, F. Biochemical composition influenced by different location inUzun pistachio CV. (Pistacia vera L.) grown in Turkey Journal of food Composition and Analysis 19 (5), 2006. $461-465$.

[16] Gepts, P. Genetic diversity of seed storage proteins in plants. In: Brown, A. H. D., Clegg, M. T., Kahler, A. L. and Weir, B. S.,Eds., 1989. Plant Population.

[17] Magni C., Scarafoni, A., Herndl, A., Sesse F., Prinsi, B., Espen, L. and Duranti, M. Combined 2D electrophoretic approaches for the study of white Lupin mature seed storage protein Phytochemistry, 68(7), 2007. 997-1007.

[18] Jansen U., Lixue C.. Abies seed protein profile divergent from other Pinaceae Taxon, 40, 1991, 435-440.

[19] Laemmli, U.K. Cleavage of structural proteins during the assembly of the head of bacteriophage T4. Nature, 227, 1970. 680685 .

[20] Chaudhary, P.S.S. Chaudhary 1988. Karyotypic studies and trend of speciation in some species of Caesalpiniaceae. Journal of Cytology and Genetics 23:183-189.

[21] Stebbins, G.L. Edward Arnold (Publ.) Ltd. London.1971. 'Chromosomal evolution in higher Plants'

[22] Kumari S. and S.S. Bir. Karyomorphological evolution in Caesalpiniaceae. Journal of Cytology and Genetics 24: 1989. 149-163.

[23] Huziwara, Y. Karyotype analysis in some genera of Compositae. VIII. Further studies on the chromosomes of Aster. Amer. J. Bot. 49, 1962.116.

[24] Singh, A. and Roy, R. P. Karyological studies in Trigonella, Indigofera and Phaseolus. Nucleus 13, 1970. $41-54$

[25] Darlington, C. D and La Cour, L. F. George Adlen and Unwin, London. 1962. The Handling of chromosomes $4^{\text {th }}$ edn.

[26] Khan, M. F., Schumann, E. and Weber, E. E. Characterization of Pakistani wheat varieties for general cultivation in the mountainous regions of Azad Kashmir. Asian Journal of Plant Science, 1(6), 2002. 699-702.

TABLE -1

Karyotypic variations in Bauhinia species

\begin{tabular}{|l|c|c|c|}
\hline Species & Chromatin Length in $\boldsymbol{\mu}$ & T.F \% & TCL in $\boldsymbol{\mu}$ \\
\hline B. acuminata & $1.81-2.92$ & 49.73 & 56.78 \\
\hline B. purpurea & $1.41-2.54$ & 46.68 & 57.32 \\
\hline B.racemosa & $1.78-2.88$ & 50.11 & 53.48 \\
\hline B. variegata & $1.41-3.01$ & 48.40 & 55.52 \\
\hline
\end{tabular}

TABLE-2

The Rf value of the bands that appeared on gel of Bauhinia species

\begin{tabular}{|l|c|l|c|c|c|c|c|}
\hline Band No. & Rf value & $\begin{array}{l}\text { Mol. Wt. } \\
\text { In KDa }\end{array}$ & Marker & B. acuminata & B. purpurea & B. racemosa & B. variegata \\
\hline 1 & 0.08 & $\mathbf{2 6 1 . 1 4 3}$ & + & + & + & + \\
\hline 2 & 0.14 & 254.77 & & - & - & + \\
\hline 3 & 0.20 & 178.34 & & - & - & - \\
\hline 4 & 0.24 & 148.622 & & - & - & + & + \\
\hline 5 & 0.26 & 147.740 & + & + & - & - \\
\hline
\end{tabular}


Cytological Diversity and Seed Storage Protein Profiling of most potent Bauhinia species

\begin{tabular}{|c|c|c|c|c|c|c|c|}
\hline 6 & 0.28 & 137.190 & & - & - & - & - \\
\hline 7 & 0.30 & 128.04 & & - & - & + & - \\
\hline 8 & 0.34 & 126.60 & & - & + & + & - \\
\hline 9 & 0.38 & 113.36 & & - & - & - & - \\
\hline 10 & 0.42 & 102.564 & & + & - & - & + \\
\hline 11 & 0.44 & 97.90 & + & - & - & - & - \\
\hline 12 & 0.47 & 91.65 & & - & - & - & + \\
\hline 13 & 0.48 & 89.74 & & + & - & + & - \\
\hline 14 & 0.51 & 54.854 & + & + & + & - & - \\
\hline 15 & 0.54 & 51.80 & & + & - & - & - \\
\hline 16 & 0.56 & 49.95 & & - & - & + & - \\
\hline 17 & 0.58 & 41.56 & & + & + & + & - \\
\hline 18 & 0.64 & 37.67 & + & - & + & - & + \\
\hline 19 & 0.75 & 31.85 & + & + & + & + & + \\
\hline 20 & 0.81 & 21.767 & + & - & - & - & + \\
\hline 21 & 0.82 & 21.50 & & - & - & - & - \\
\hline 22 & 0.90 & 7.337 & + & + & + & + & + \\
\hline
\end{tabular}

TABLE- 3

Percentage Similarity Index between Bauhinia Species

\begin{tabular}{|c|c|c|}
\hline S. No. & Species x Species & Percentage Similarity \\
\hline 1 & B. acuminata x B. purpurea & $45.45 \%$ \\
\hline 2 & B. acuminata $\times$ B. racemosa & $33.33 \%$ \\
\hline 4 & B. acuminata $\times$ B. variegata & $33.33 \%$ \\
\hline 5 & B. purpurea $\times$ B. racemosa & $38.46 \%$ \\
\hline 6 & B. purpurea $\times$ B. variegata & $40.00 \%$ \\
\hline 7 & B. racemosa x B. variegata & $20.00 \%$ \\
\hline
\end{tabular}

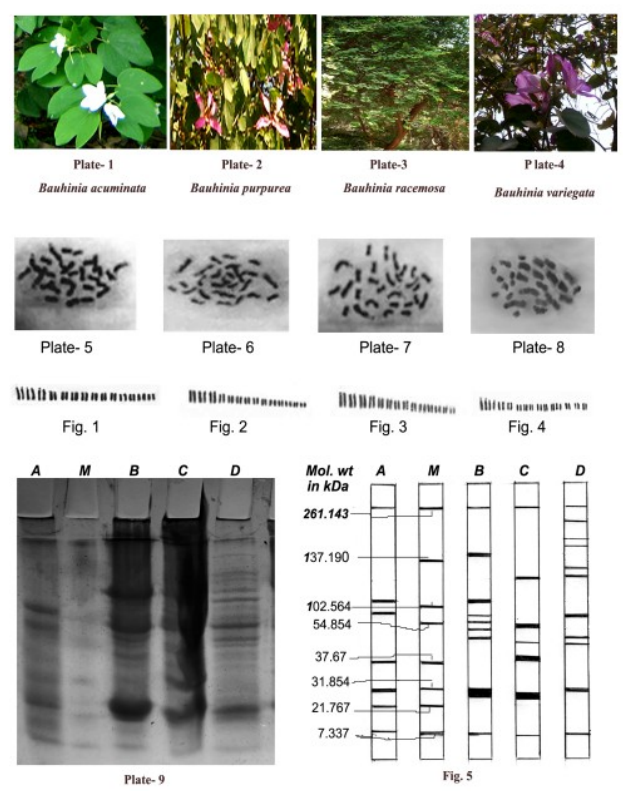

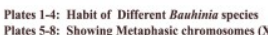

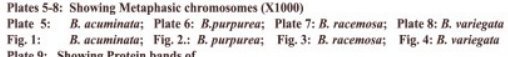

Plate 9: Showing Protein bands of $[$ A

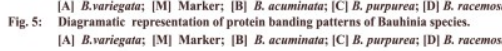

